Brazilian Journal

of Chemical

Engineering

\title{
LIGHT N-PARAFFINS SEPARATION BY INVERSE GAS CHROMATOGRAPHY WITH CUBAN VOLCANIC GLASS
}

\author{
Miguel Autie-Pérez ${ }^{1 *}$, Antonia Infantes-Molina ${ }^{2}$, Juan Antonio Cecilia ${ }^{2}$, \\ Juan M. Labadie-Suarez ${ }^{1}$, Heydy Fernández-Echevarría ${ }^{1}$, \\ José Santamaría-González ${ }^{2}$ and E. Rodríguez-Castellón ${ }^{2 *}$

\footnotetext{
${ }^{1}$ Instituto Superior Politécnico José Antonio Hechevarría, Facultad de Ingeniería Química, Departamento FQB, Habana, Cuba. E-mail: aautie@gmail.com E-mail: castellon@uma.es, ORCID: 0000-0003-4751-1767
} \\ ${ }^{2}$ Universidad de Málaga, Facultad de Ciencias, Departamento de Química Inorgánica, Cristalografía y Mineralogía, Málaga, Spain.
}

(Submitted: September 5, 2017 ; Revised: January 6, 2018 ; Accepted: February 1, 2018)

\begin{abstract}
In this work the applicability of a natural volcanic glass (technological type I material) from Cuba is investigated as adsorbent for separation of mixtures of $\mathrm{C}_{1}-\left(\mathrm{C}_{5}, \mathrm{C}_{6} ; \mathrm{C}_{7} ; \mathrm{C}_{8} ; \mathrm{C}_{9}\right)$ hydrocarbons by inverse gas chromatography under flow conditions in a temperature range of 328-343 $\mathrm{K}$. The experimental results indicated that the material was mainly composed of silica and, in a lower proportion, of alumina, that provided surface $\mathrm{Si}$ $\mathrm{OH}$ and $\mathrm{Al}-\mathrm{OH}$ groups to favor the interaction and separation of the different components of paraffin mixtures. In fact, the calculated heats of adsorption were high enough to facilitate the separation procedure. The high availability and low cost of these materials make them potential and attractive candidates to be used in large scale applications.
\end{abstract}

Keywords: Adsorption; Separation; Linear paraffins; Glasses; Diffusion; Surface properties.

\section{INTRODUCTION}

The separation of individual components of paraffin mixtures is a key factor in the petrochemical industry. These products are one of the most important components of natural gas, fuel and lube oils due to their huge resources and relatively non-toxicity in comparison to other sources because the combustion of these products does not cause any formation of harmful products.

Several methods have been proposed to separate olefin/paraffin in industry (Brian, 2004). Among them, the common separation processes are absorption (Laredo et al., 2012; Gomes et al., 2014), cryogenic distillation (Torres-Ortega et al., 2013), and membranes (Merkel et al., 2013). Absorption is the most sustainable process to separate olefins and paraffins due to the complexation of the double bond of the olefins with transition metals (Dewar, 1951; Eldridge, 1993). However, paraffins are exclusively formed by $\mathrm{C}-\mathrm{H}$ bonds so the interactions required by the adsorption process must be non-specific. The fuel companies use molecular sieves such as carbons (Huang et al., 2011; Yahia and Ouederni, 2012) or zeolites (Rivera et al., 2011; Ferreira et al., 2013). Zeolites are molecular sieves with a well-defined microporous framework, which leads to efficient adsorbents and catalysts with high thermal stability (Beerdsen, et al., 2003); while activated carbons have also shown an excellent behavior in adsorption and separation processes. Nonetheless, the design and synthesis of these adsorbents raises the cost of the separation process, mainly in the case of activated carbons (He et al., 2012). In order to improve competitiveness, inexpensive adsorbents with high

\footnotetext{
*Corresponding authors: Miguel Autie-Pérez and E. Rodríguez-Castellón - E-mail: aautie@gmail.com; castellon@uma.es
} 
availability in the environment such as natural zeolites have been proposed (Rivera et al., 2011).

The aim of the present work is the search and development of alternative materials to separate these light paraffins. In this sense, a volcanic glass has been proposed as a potential material for this process due to its high availability and low cost. Volcanic glass is a natural glass, which results from the rapid cooling of lava. The physicochemical properties of these materials depend on the chemical composition of magma and its cooling rate (Friedman and Long, 1984). Volcanic glass has been used as starting material for the synthesis of zeolites (Yoshida and Inoue, 1986; Yoshida and Inoue, 1988) or smectites (Tomita et al., 1993), the adsorption of radioactive ions (Steinhauser and Bichler, 2008), arsenic (Ruggieri et al., 2008) or copper (Alkan and Dogan, 2001), the adsorption of dyes such as methylene blue (Dogan et al., 2004) methyl violet (Dogan and Alkan, 2003), victoria blue (Alkan and Dogan, 2003), the synthesis of composites with polyacrylamide (Tekin et al., 2010) and more recently in the separation of propane/propylene (Fernández-Hechevarría et al., 2015).

The adsorption and later separation of light alkane hydrocarbons using Inverse Gas Chromatography (ICG) has been widely reported in the literature. IGC is a highly selective and versatile gas phase technique to perform physicochemical characterization of different solids. It is based on injection of clearly identified molecules into a column packed with the material under investigation (Mohammadi-Jan and Waters, 2014). The interaction between adsorbate-adsorbent will determine the retention time and therefore the capacity to separate the mixture and will provide information on thermodynamics, surface energy, reaction kinetics, and textural parameters (such as specific surface area and porosity) (Lazarević et al, 2009). The surface energy of solid materials is an important property that controls many practical applications and is a direct manifestation of intermolecular forces. In the case of a $n$-paraffin mixture it would provide information about the differential adsorption heat as a function of the carbon number in the paraffins under study.

The most attractive aspect of the IGC is the effective application to a wide range of physicochemical characterization of non-volatile materials such as dispersive and specific parameters of surface free energy, diffusion coefficient, phase transitions and crystallinity (Voelkel et al., 2009; Mohammadi-Jan and Waters, 2014), which can yield vital information in the fields of polymer and coatings (Edelman and Fradet, 1989; Murakami et al., 1998; Abel et al., 2002), pharmaceuticals (Grimsey et al., 2002; Planinsek and Buckton, 2003; Mohammadi-Jan and Waters, 2014) fibers (Cantergiani and Benczédi, 2002; Heng et al., 2007) or nanomaterials (Batko and Voelkel, 2007;
Menzel et al., 2009). Basing on the physicochemical properties of the material introduced on the packed column, IGC can be used for the separation of paraffins, as was reported by Autie et al. in previous researches using porous hexacyanocobaltates (Autié-Castro et al., 2009), metal-organic framework (Cu-BTC and Fe-BTC) (Autié-Castro et al., 2015) or natural clinoptilolite (Rivera et al., 2011). In the present work, a packed column with inexpensive volcanic glass has been used to evaluate the separation capacity of this structure for $\mathrm{C}_{5}-\mathrm{C}_{9}$ paraffin mixtures as well as their adsorption heats by IGC.

\section{MATERIALS AND METHODS}

The material used for the separation of paraffins by IGC was a volcanic glass obtained from the Aji de la Caldera mine in Guantanamo (Cuba). The chemical composition of this volcanic glass was evaluated by wavelength disperse X-ray fluorescence (ARL ADVANTXP spectrometer) and UNIQUANT software.

The crystalline phases were determined using a X'Pert PRO MPD Philips diffractometer with $\mathrm{CuK}_{\alpha}$ $(1.54 \AA \AA)$ radiation.

FT-IR spectra were collected with a Varin 3100 FTIR spectrophotometer with a Harrick HVC-DRP cell. The analysis of the volcanic glass was carried out using about $30 \mathrm{mg}$ of finely ground sample. The interferograms consisted of 120 scans and the spectrum was collected using a $\mathrm{KBr}$ spectrum as a background.

The textural properties of the volcanic glass were determined by $\mathrm{N}_{2}$ adsorption-desorption at 77 $\mathrm{K}$ in a Micromeritics ASAP 2020 equipment. Prior to analysis, volcanic glass was outgassed at $673 \mathrm{~K}$ and $0.01 \mathrm{kPa}$ for $12 \mathrm{~h}$. The specific surface area was determined using the Brunauer-Emmett-Teller (BET) equation considering a $\mathrm{N}_{2}$ molecule cross section of $16.2 \AA^{2}$ (Brunauer et al., 1938). The porosity of the volcanic glass was measured by Hg-Porosimetry using an AutoPore IV 9500 V1.07 equipment supplied by Micromeritics in a pressure range of $0.0034 \mathrm{e} 224 \mathrm{MPa}$

The IGC data were recorded with Shimadzu equipment (model 14B) and a flame ionization detector (FID) in the 368-488 $\mathrm{K}$ temperature range. Helium was used as carrier gas at a flow rate of $12.8 \mathrm{~cm}^{3} /$ min. Previously cleaned and weighed stainless steel columns $(60 \mathrm{~cm}$ long and $2.2 \mathrm{~mm}$ inner diameter) were packed with $2.5 \mathrm{~g}$ of the material. The packed columns were outgassed overnight at $523 \mathrm{~K}$ under helium flow. $n$-Alkanes of analytical grade were used in all cases and injected as the smallest detectable amount of their vapor phases, extracted from the head space of their containers, to obtain data close to zero coverage.

To obtain the corrected retention time for the probes the relation $\left(\mathrm{t}_{\mathrm{R}}-\mathrm{t}_{0}\right)$ was used, where $\mathrm{t}_{0}$ was the retention 
time of methane, $\mathrm{CH}_{4}$ (un-retained hydrocarbon), and $t_{R}$ was the retention time of the probe. The corrected retention times were taken as the average number value among five injections. Mixtures of $\mathrm{C}_{1}-\left(\mathrm{C}_{5}\right.$;---; $\mathrm{C}_{9}$ ) were prepared by introduction of a little quantity of $\mathrm{CH}_{4}$ in the head space of each liquid alkane, and $\mathrm{C}_{5}-\mathrm{C}_{9}$ net retention volumes, $V_{\mathrm{n}}$, were calculated according to Eq. 1:

$$
\mathrm{V}_{\mathrm{n}}=\mathrm{J} \cdot \mathrm{V}_{\mathrm{f}} \cdot\left(\mathrm{t}_{\mathrm{R}}-\mathrm{t}_{0}\right) \cdot \frac{\mathrm{T}_{\mathrm{c}}}{\mathrm{T}_{\mathrm{A}}} \cdot \frac{\left(\mathrm{P}_{0}-\mathrm{P}_{\mathrm{w}}\right)}{\mathrm{P}_{0}}
$$

where $\mathrm{J}$ is the James-Martin gas compressibility correction factor, $\mathrm{V}_{\mathrm{f}}$ is the gas carrier flow rate at the flow meter temperature $T_{f} ; T_{C}$ is the column temperature; $\mathrm{T}_{\mathrm{A}}$ is the room temperature $\left(\mathrm{T}_{\mathrm{A}}=\mathrm{T}_{\mathrm{f}}\right) ; \mathrm{P}_{0}$ is the outlet pressure; $P_{w}$ is the vapor pressure of water at $\mathrm{T}_{\mathrm{f}}$.

The differential adsorption heat, $Q_{d}$, equal to the enthalpy for the standard adsorbed state $\Delta \mathrm{H}_{\mathrm{d} 0}$ (within the Henry zone) was determined from the slope of a $\ln \left(\mathrm{V}_{\mathrm{n}} / \mathrm{A}_{\mathrm{S}}\right)$ versus $1 / \mathrm{T}_{\mathrm{C}}$ plot according to equation (2):

$$
\mathrm{Q}_{\mathrm{d}}=\Delta \mathrm{H}_{\mathrm{d} 0}=-\mathrm{R} \cdot \frac{\mathrm{d}\left[\ln \left(\mathrm{V}_{\mathrm{n}} / \mathrm{A}_{\mathrm{S}}\right)\right]}{\mathrm{d}\left(1 / \mathrm{T}_{\mathrm{C}}\right)}
$$

where $\mathrm{R}$ is the universal gas constant; and $\mathrm{A}_{\mathrm{s}}$ is the product of the specific surface area $(\mathrm{S})$, and the amount of sample (m) in the column.

\section{RESULTS AND DISCUSSION}

The chemical composition of the volcanic glass was estimated by X-ray fluorescence (XRFS) (Figure 1). These data reported that the material is mainly formed by $\mathrm{SiO}_{2}(66.3 \%)$ and $\mathrm{Al}_{2} \mathrm{O}_{3}(13.4 \%)$. In addition, it is noteworthy the presence of other oxides such as, $\mathrm{Fe}_{2} \mathrm{O}_{3}, \mathrm{MgO}, \mathrm{CaO}, \mathrm{NaO}$ or $\mathrm{K}_{2} \mathrm{O}$ in minor proportions. Several authors have reported that basaltic magmas, which contain $\mathrm{SiO}_{2}(<50 \%)$ are very fluid and their lower viscosity favors the crystallization. However, the highly polymerized rhyolitic lavas that contain higher $\mathrm{SiO}_{2}$ proportions $(>65 \%)$ are extremely viscous, yielding a layer of obsidian as much as meters to tens of meters thick (Friedman and Long, 1984). Considering this fact, the volcanic glass analyzed in this research should come from rhyolitic lavas that suffered a relatively slow cooling.

The XRD diffractogram of the volcanic glass showed a noisy profile (Figure 2), with a broad band from $20-30^{\circ}$ attributed to the presence of an amorphous structure. Thus, it is noteworthy the presence of

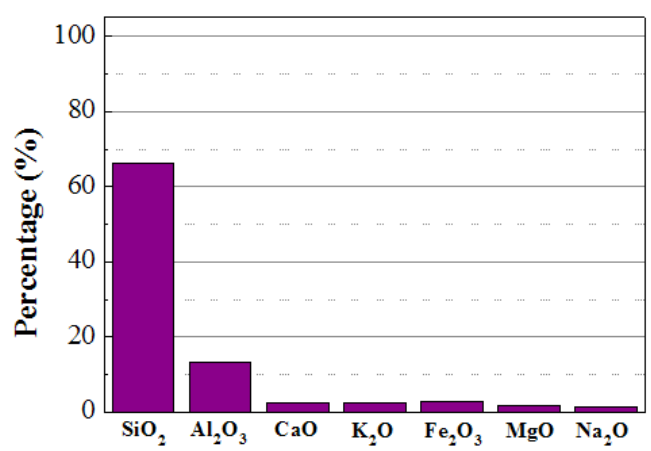

Figure 1. Chemical composition of the volcanic glass (estimated by XRFS).

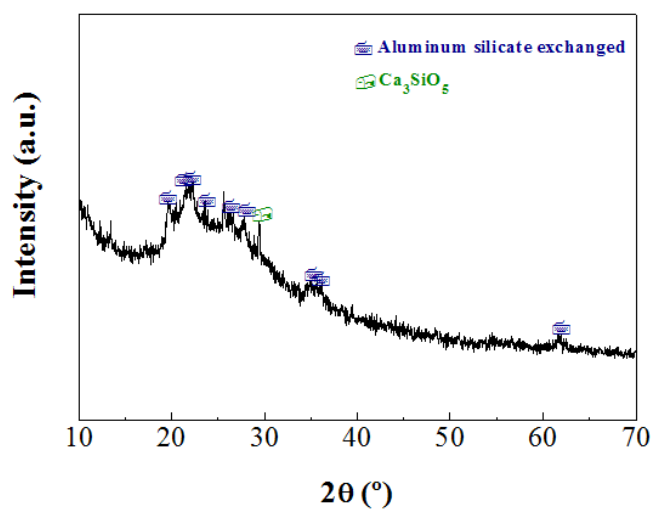

Figure 2. X-ray diffraction patterns of the volcanic glass.

small diffraction peaks, which are attributed to the substitution of silicon by aluminum in the quasiamorphous aluminosilicates, leading to a charge deficiency that is counterbalanced by the presence of alkaline cations, such as $\mathrm{Na}^{+}$or $\mathrm{K}^{+}$. In addition, the diffraction peak located at about $2 \theta=22.9^{\circ}$, attributed to $\mathrm{Ca}_{3} \mathrm{SiO}_{5}$, indicates the presence of another phase with higher crystallinity, although in low proportion. If this material is compared with another volcanic glass from Brazil (Andrade et al., 2018), the studied Volcanic glass was much less crystalline and also presented a different composition. Thus, the volcanic glass from Brazil presented labradorite, augite, quartz, cristobalite, sanidine, alumina, magnetite, pigeonite, enstatite and apatite. It is clear that both the composition and crystallinity depend on the origin of the volcanic glass, as expected.

Figure 3A shows the FT-IR spectrum of the volcanic glass between $4000-2750 \mathrm{~cm}^{-1}$. The band located about $3600 \mathrm{~cm}^{-1}$ is attributed to the $\mathrm{OH}$ stretching modes of the structural $\mathrm{OH}$ groups (Franco et al., 2016), while the broad band close to $3430 \mathrm{~cm}^{-1}$ is attributed to the overlapping asymmetric and symmetric ( $\mathrm{H}-\mathrm{O}-\mathrm{H})$ stretching vibrations of H-bonded water (Madejová, 2003). The shoulder located about $3230 \mathrm{~cm}^{-1}$ is ascribed to an overtone of the bending mode of cation hydration water (Farmer, 1974). Figure 3B displays the FT-IR spectrum between $1800-750 \mathrm{~cm}^{-1}$. The main 
band located at about $1290 \mathrm{~cm}^{-1}$ is attributed to $\mathrm{Si}-\mathrm{O}$ stretching of the amorphous aluminosilicate, while the band about $1160 \mathrm{~cm}^{-1}$ is assigned to the $\mathrm{Si}-\mathrm{O}$ stretching mode typical of the clay minerals (Madejová, 2003). In this sense, previous researches have pointed out that volcanic glass can suffer an alteration process to form zeolites or smectites (Tomita et al., 1993). The band located about $980 \mathrm{~cm}^{-1}$ is attributed to the $\mathrm{Si}-\mathrm{O}$ in-plane stretching vibrations, while the bands located about $900 \mathrm{~cm}^{-1}$ and $790 \mathrm{~cm}^{-1}$ are assigned to the Al-O$\mathrm{Si}$ and $\mathrm{Si}-\mathrm{O}-\mathrm{Si}$ bending modes (Vilarrasa-García et al., 2017). The weak shoulder centered at about $1450 \mathrm{~cm}^{-1}$ is attributed to the presence of $\mathrm{CO}_{3}{ }^{2-}$ species (Correia et al., 2015). Finally, the band with a maximum located at $1640 \mathrm{~cm}^{-1}$ is assigned to the $\mathrm{H}-\mathrm{O}-\mathrm{H}$ bending vibrations (Vilarrasa-García et al., 2017).

The textural properties were determined from the experimental adsorption isotherm of $\mathrm{N}_{2}$ at $77 \mathrm{~K}$ (Figure 4). The isotherm is of type II according to the IUPAC classification, which is attributed to the presence of mesoand mainly macropores by the existence of interparticle voids (Thommes et al., 2015). The specific surface area was determined considering the linearity in the range of $\mathrm{P} / \mathrm{P}_{0}(0.10-0-25)$, which is ascribed to $\mathrm{N}_{2}$-adsorption on the monolayer, obtaining a value of $44 \mathrm{~m}^{2} / \mathrm{g}$. This value is well below other porous materials, such as zeolites or activated carbon that can reach specific surface areas even more than $1000 \mathrm{~m}^{2} / \mathrm{g}$. Previous researches have evaluated the textural properties of other volcanic glass coming from Turkey, obtaining $\mathrm{S}_{\mathrm{BET}}$ values lower than $10 \mathrm{~m}^{2} / \mathrm{g}$, probably due to the bigger particle size, which implies a decrease of the available surface (Dogan and Alkan, 2003; Dogan et al., 2004).

As was indicated previously, the $\mathrm{N}_{2}$-isotherm at $77 \mathrm{~K}$ revealed that the volcanic glass presented macroporosity, as observed from the sharp $\mathrm{N}_{2}$ adsorption at high relative pressures, so the most appropriate technique to evaluate the porosity is $\mathrm{Hg}$ porosimetry. It should be stated that Figure $5 \mathrm{~A}$ reveals

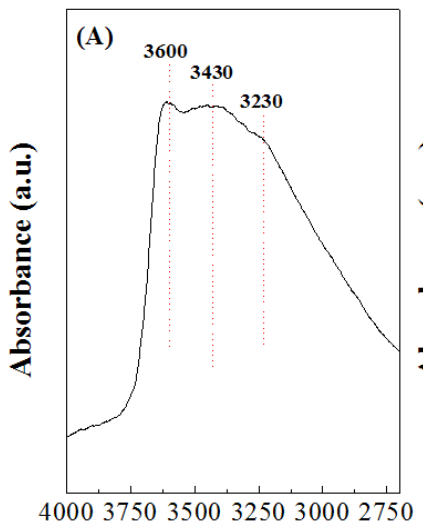

Wavenumber $\left(\mathbf{c m}^{-}{ }^{1}\right)$

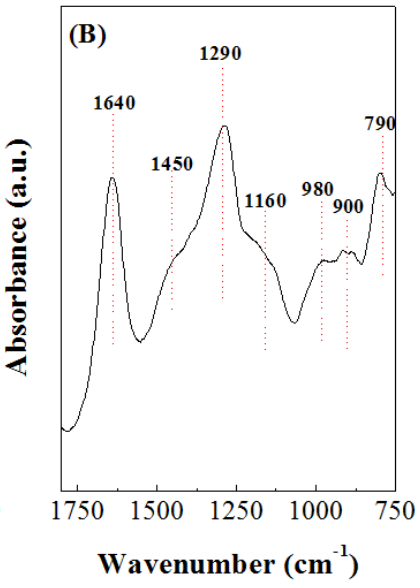

Figure 3. FTIR in the range of $4000-2700 \mathrm{~cm}^{-1}$ (A) and $1800-750 \mathrm{~cm}^{-1}(\mathrm{~B})$ of the volcanic glass.

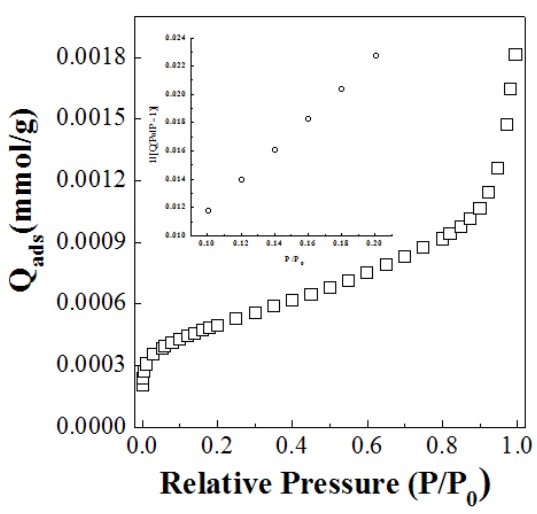

Figure 4. $\mathrm{N}_{2}$ adsorption isotherm at $77 \mathrm{~K}$ of the volcanic glass.

Hg-intrusion until $25 \mathrm{MPa}$ characteristic of the filling of the voids between particles. From this pressure value, the volume barely changed, which indicates the absence of pores of small diameter. Figure 5B confirms this fact with about $90 \%$ of the pore volume inside of the macropore range, i.e., pore diameter higher than $50 \mathrm{~nm}$, while only $10 \%$ can be considered as small macropores and mesopores.

Several experiments were carried out to understand the separation capability of paraffins in the volcanic glass. Figures 6-9 show the chromatographic profiles of several n-paraffin mixtures under different operational conditions. From these figures, it can be clearly observed that in all cases well-defined and symmetric elution peaks appeared. The adsorption process takes place following Henry's law where the interactions with neighboring molecules are nonspecific and with scarce intensity. In all cases, it can be observed that an increase of the paraffin length favors its retention on the column. Considering that the volcanic glass is mainly macroporous, as indicated from the Hg-porosimetry, the existence of higher nonspecific interaction between the longer carbon-chain paraffins and the volcanic glass is expected.
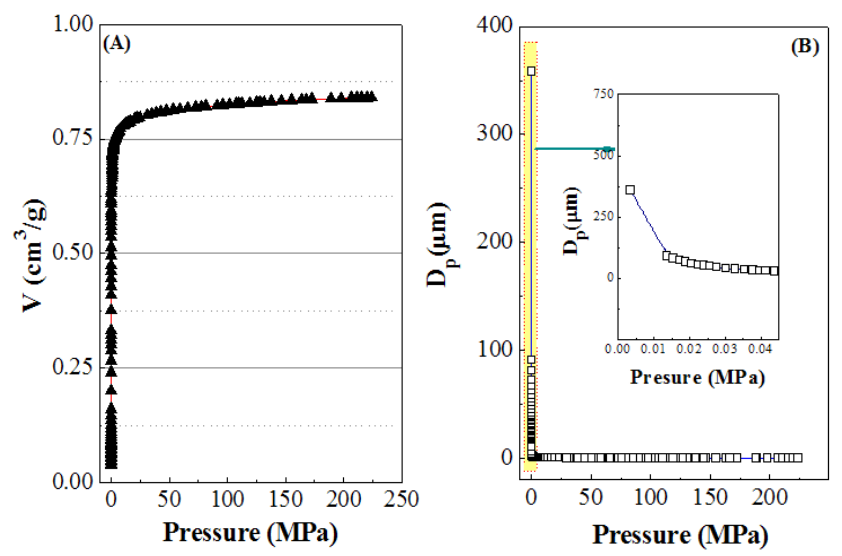

Figure 5. Hg-porosimetry profile (A) and pore diameter obtained from $\mathrm{Hg}$-porosimetry as a function of the experimental pressure (B) for the volcanic glass. 


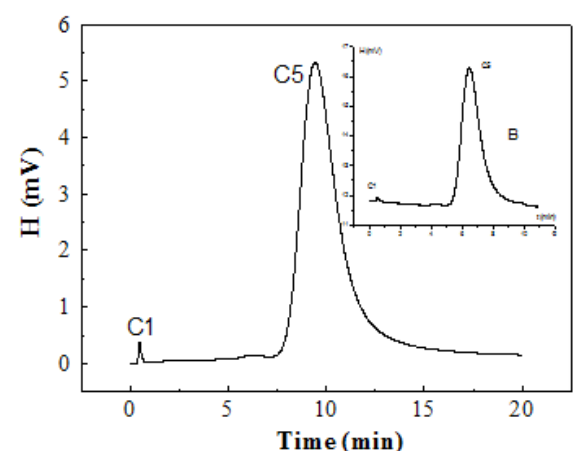

Figure 6. Chromatogram of $\mathrm{C} 1+\mathrm{C} 5$ at $368 \mathrm{~K}(\mathrm{~A})$ and $378 \mathrm{~K}(\mathrm{~B})$ in the volcanic glass.

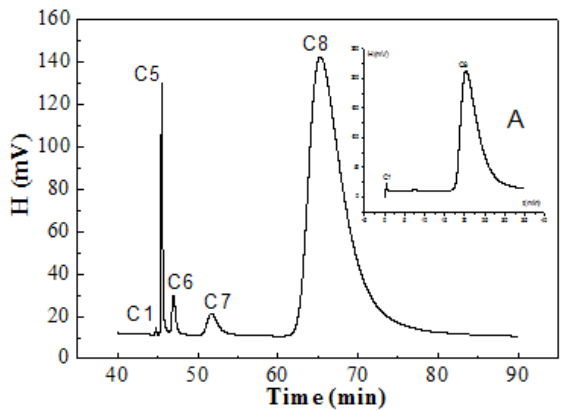

Figure 7. Chromatogram of $\mathrm{C} 1+\mathrm{C} 8(\mathrm{~A})$ and mixture of $\mathrm{C} 1+\mathrm{C} 5+\mathrm{C} 6+\mathrm{C} 7+\mathrm{C} 8(\mathrm{~B})$ at $448 \mathrm{~K}$ in the volcanic glass.

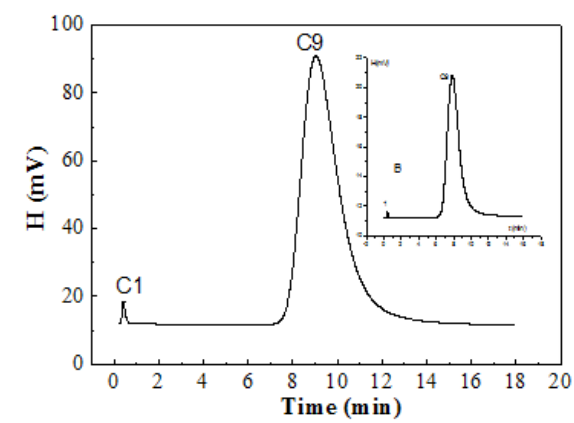

Figure 8. Chromatogram of $\mathrm{C} 1+\mathrm{C} 9$ at $473 \mathrm{~K}(\mathrm{~A})$ and $478 \mathrm{~K}(\mathrm{~B})$ in the volcanic glass.

The graphs of $\ln V n$ vs. 1/Tc for every paraffin, represented in Figures 10 and 11, were a straight line in all cases with $\mathrm{R}>0.99$. The values of the differential heats of adsorption calculated from the slopes are included in Table 1.

From this table, it is observed that the heats of adsorption followed the order:

$\mathrm{Q}_{\mathrm{d}} \mathrm{C}_{9} \mathrm{H}_{20}>\mathrm{Q}_{\mathrm{d}} \mathrm{C}_{8} \mathrm{H}_{18}>\mathrm{Q}_{\mathrm{d}} \mathrm{C}_{7} \mathrm{H}_{16}>\mathrm{Q}_{\mathrm{d}} \mathrm{C}_{6} \mathrm{H}_{14}>\mathrm{Q}_{\mathrm{d}} \mathrm{C}_{5} \mathrm{H}_{12}$

That is, it increased with the carbon number. If $Q_{d}$ is represented vs the number of carbons of the paraffin molecule, a linear correlation was observed. The fitting was a straight line with $\mathrm{R}>0.99$ (Figures 10-11). This is explained by considering that $n$-paraffin interactions with the solid are of the van der Walls-type (i.e., non-

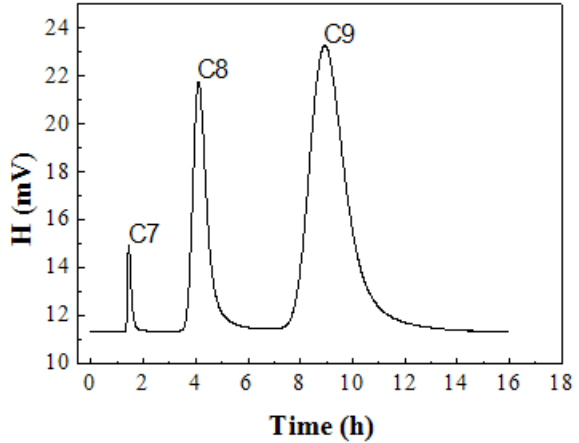

Figure 9. Chromatogram of $\mathrm{C} 7+\mathrm{C} 8+\mathrm{C} 9$ mixture at $\mathrm{Tc}$ $=478 \mathrm{~K}$ in in the volcanic glass.
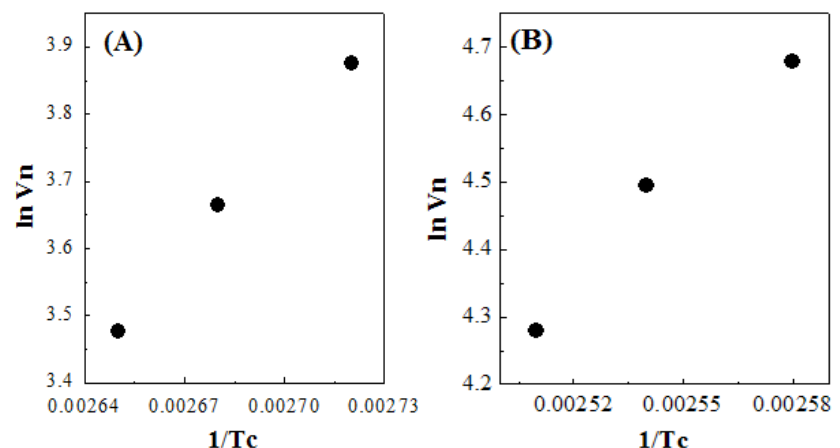

Figure 10. Ln Vn vs. 1/Tc for C5 at 368-378 K (A) and for $\mathrm{C} 6$ at $388-398 \mathrm{~K}(\mathrm{~B})$ in the volcanic glass.
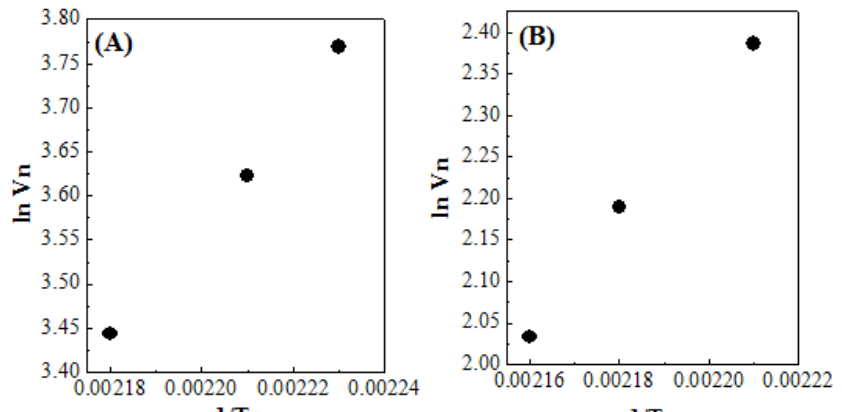

$1 / \mathrm{Tc}$

$1 / \mathrm{Tc}$

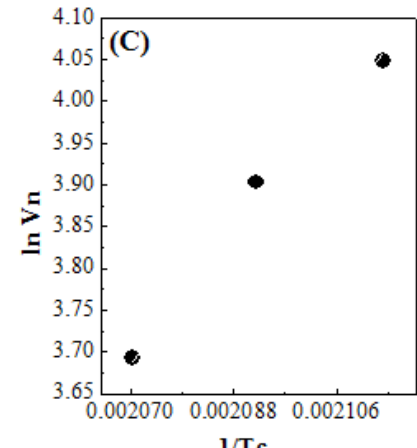

Figure 11. Ln Vn vs $1 / \mathrm{Tc}$ corresponding to $\mathrm{C} 7$ at 448 $458 \mathrm{~K}(\mathrm{~A})$; C8 at 453-463 K (B) and C9 at 473-483 K in the volcanic glass.

specific type) and each $\mathrm{CH}_{2}$ group contributes in the same way. This fact leads to a higher slope value for the longer carbon-chain paraffins, reaching the maximum 
Table 1. n-Paraffin (HC) adsorptions heats in $\mathrm{kJmol}^{-1}$ $\left(\mathrm{Q}_{\mathrm{di}}\right)$, adsorption differences heats of two neighboring n-paraffin $\left(\Delta \mathrm{Q}_{\text {dif }}\right)$ in $\mathrm{kJmol}^{-1}$ and their Bering-Serpinskii separation capacity $\mathrm{K}_{\mathrm{BS}}$ in the volcanic glass.

\begin{tabular}{cccc}
\hline $\mathbf{H C}$ & $\mathbf{Q}_{\text {dif }}$ & $\Delta \mathbf{Q}_{\text {dif }}$ & $\mathbf{K}_{\mathbf{B}-\mathbf{S}}$ \\
\hline $\mathrm{C}_{5} \mathrm{H}_{12}$ & 42.7 & ----- & ---- \\
$\mathrm{C}_{6} \mathrm{H}_{14}$ & 51.3 & 8.6 & 2.1 \\
$\mathrm{C}_{7} \mathrm{H}_{16}$ & 55.9 & 4.6 & 1.2 \\
$\mathrm{C}_{8} \mathrm{H}_{18}$ & 61.5 & 5.6 & 1.4 \\
$\mathrm{C}_{9} \mathrm{H}_{20}$ & 67.4 & 5.9 & 1.5 \\
\hline
\end{tabular}

differential adsorption heat $(67.4 \mathrm{~kJ} / \mathrm{mol})$ for $\mathrm{C}_{9} \mathrm{H}_{20}$, while $\mathrm{C}_{5} \mathrm{H}_{12}$ only displays a differential adsorption heat of $42.7 \mathrm{~kJ} / \mathrm{mol}$. In addition, it was possible to know the contribution of each $\mathrm{CH}_{2}$ of a paraffin group from the slope of the straight lines, obtaining a $\mathrm{Q}_{\text {dif }}$ around $5.3 \mathrm{~kJ} / \mathrm{mol}$. If the differences between these values are calculated (Table 1), all of them are much higher than 1 , indicating that volcanic glass has excellent behavior in the separation of light paraffins.

On the other hand, Bering and Serpinski (Keltsev, 1984) pointed out that the separation criterion $\left(\mathrm{K}_{\mathrm{B}-\mathrm{S}}\right)$ is not determined by adsorption heat values, but by the difference between them. Thus, $\ln \mathrm{K}_{\mathrm{B}-\mathrm{s}}$ values greater than 1 indicate that two neighboring components in the chromatogram could be completely separated. Greater values of $\ln \mathrm{K}_{\mathrm{BS}}$ indicate that a better separation will be obtained. $\ln \mathrm{K}_{\mathrm{B}-\mathrm{S}}$ was calculated from Equation 3.

$\ln \mathrm{K}_{\mathrm{B}-\mathrm{S}}=\frac{\mathrm{Q}_{\mathrm{Dif2}}-\mathrm{Q}_{\text {Dif1 }}}{\mathrm{RT}}$

Moreover, Figure 7 shows that, for a high temperature such as $448 \mathrm{~K}$, the use of volcanic glass can resolve the $\mathrm{C}_{5}-\mathrm{C}_{8}$ mixture with well definite peaks. At $478 \mathrm{~K}$ the $\mathrm{C}_{7}+\mathrm{C}_{8}+\mathrm{C}_{9}$ mixture is also well resolved (Figure 8). The $\mathrm{Q}_{\text {dif }}$ values suggested that the volcanic glass may separate a complex mixture of light n-paraffins $\mathrm{C}_{5}-\mathrm{C}_{9}$ with well defined peaks in adequate conditions of fluxes and temperatures as was shown experimentally in Figures 12-13.

When the adsorption heat values of n-paraffins in volcanic glass were compared with those obtained

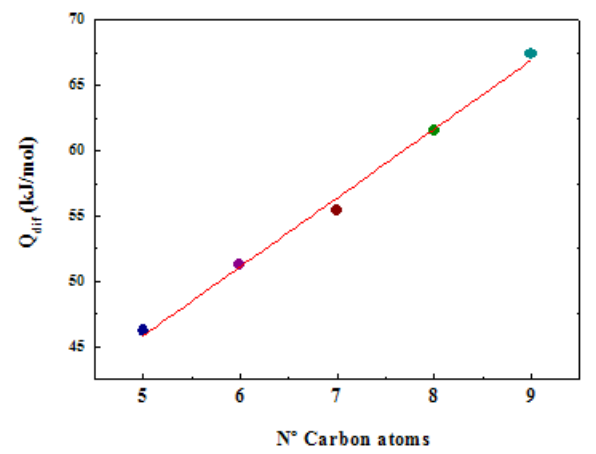

Figure 12. $Q_{\text {dif }}$ vs. number of carbon atoms C5-C9 in the volcanic glass.

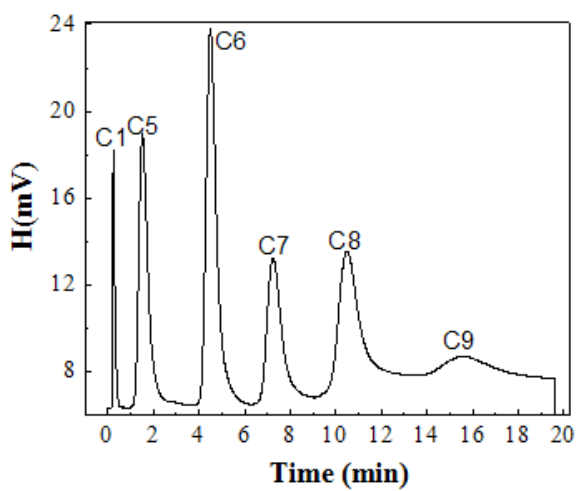

Figure 13. Chromatogram of $\mathrm{CH}_{4}+\mathrm{C} 5-\mathrm{C} 9$ mixture in the volcanic glass $(\mathrm{Tc}=400 \mathrm{~K}+5 \mathrm{~K} / \mathrm{min})$.

in other crystalline materials, it was observed that, although the studied volcanic glass is an amorphous mineral with macroporous and mesoporous surface, the n-paraffin-surface interactions were sufficiently strong to separate the components of a $\mathrm{C}_{5}-\mathrm{C}_{9}$ mixture (Table 2 and Figure 13). The data shown in this research are in the same range as those reported in the literature for MOFs (Autié-Castro et al., 2015) and natural zeolites (Rivera et al., 2011), previously. Table 2 results indicated that, in spite of the lower specific surface area, its capacity to separate paraffins was similar to material presenting higher surface area. It must be considered that volcanic glass is highly available in the mines.

As was indicated previously, the volcanic glasses are formed by a disordered and quasi-amorphous structure where a proportion of $\mathrm{Si}^{4+}$ are replaced by $\mathrm{Fe}^{3+}$ and $\mathrm{Mg}^{2+}$ species, which causes a charge deficiency that is neutralized by $\mathrm{Ca}^{2+}, \mathrm{Na}^{+}$or $\mathrm{K}^{+}$. These cations could be substituted by ionic exchange so volcanic glasses could be used as adsorbent of cations. A previous research has reported that volcanic glasses are efficient materials for ethane-ethylene separation (Fernández-Hechevarría et al., 2015), since the higher electronic density generated by the double bond of the ethylene molecule favors a stronger interaction with the volcanic glass in comparison to the $\mathrm{C}-\mathrm{C}$ bond. In the case of the paraffins, the exclusive presence of C-C and $\mathrm{C}-\mathrm{H}$ bonds implies that the interactions must be non-specific. Nonetheless, it is well known that the

Table 2. n-Paraffin (HC) adsorption heat in $\mathrm{kJmol}^{-}$ ${ }^{1}\left(Q_{\text {dif }}\right)$ in $\mathrm{VVN}$ and in other materials reported in different works.

\begin{tabular}{ccccc}
\hline $\mathbf{H C}$ & $\mathbf{Q}_{\text {dif }}$ & $\mathbf{Q}_{\text {dif(B) }}$ & $\mathbf{Q}_{\text {FeBTC(C) }}$ & $\mathbf{Q}_{\text {dif(D) }}$ \\
\hline $\mathrm{C}_{5} \mathrm{H}_{12}$ & 42.7 & 57 & 49.9 & 33.4 \\
$\mathrm{C}_{6} \mathrm{H}_{14}$ & 51.3 & 63.9 & 51.1 & 38.8 \\
$\mathrm{C}_{7} \mathrm{H}_{16}$ & 55.9 & 70.2 & 52.5 & 43.7 \\
$\mathrm{C}_{8} \mathrm{H}_{18}$ & 61.5 & 76.9 & 53.8 & 48.3 \\
$\mathrm{C}_{9} \mathrm{H}_{20}$ & 67.4 & 83.5 & 55.2 & 51.6 \\
\hline
\end{tabular}

(B): $\mathrm{Cu}-\mathrm{BTC}$ metal-organic frameworks (Autié-Castro, G., 2015); (C): FeBTC metal-organic frameworks (Autié-Castro, G., 2015); (D): Cliptonite (Rivera A., 2011). 
increase of the hydrocarbon chain causes an increase of the van der Waals and London interactions. These interactions must be related with the textural properties of the volcanic glass. Considering the low ordering and low surface area value, it seems clear that the interactions volcanic glass-olefin must take place on the surface of the material, discarding the presence of an ordered nanostructure such as zeolite-A, zeolite-X or zeolite-Y, that can act as molecular sieves. The obtained data reveal how the paraffins with longer chains appear at higher retention time, which is ascribed to stronger non-specific interaction (London and van der Waals) with the surface of the amorphous volcanic glass.

\section{CONCLUSIONS}

A natural volcanic glass has been used as stationary phase to separate complex mixtures of light hydrocarbons $\mathrm{C}_{5}+\mathrm{C}_{6}+\mathrm{C}_{7}+\mathrm{C}_{8}+\mathrm{C}_{9}$ at programed temperature conditions by inverse gas chromatography. The volcanic glass showed similar adsorption heats and separation capacity to those reported in the literature for crystalline materials. Moreover, the non-specific interactions between the surface and n-alkanes $\mathrm{C}_{1}---\mathrm{C}_{9}$ give rise to a sufficiently high heat of adsorption to separate these light n-paraffins. The low cost of these materials makes it a promising material to be used on larger scale to separate great volumes of mixtures and obtain pure components of $\mathrm{C}_{5}----\mathrm{C}_{9}$ paraffins.

\section{ACKNOWLEDGEMENTS}

Thanks to projects RTI2018-099668-B-C22 (Ministerio de Ciencia, Innovación y Universidades, Spain and FEDER Funds) and P12-RNM-1565 (Junta de Andalucía, Spain). A.I.M. thanks the Ministry of Economy and Competitiveness for a Ramón y Cajal contract (RyC2015-17870).

\section{REFERENCES}

Abel, M. L., Chehimi, M. M., Fricker, F., Delamar, M., Brown, A. M. and Watts, J. F., Adsorption of poly(methyl methacrylate) and poly(vinyl chloride) blends onto polypyrrole: Study by X-ray photoelectron spectroscopy, time-of-flight static secondary ion mass spectroscopy, and inverse gas chromatography. Journal of Chromatography A, 969, 273-285 (2002). https://doi.org/10.1016/ S0021-9673(02)00894-4

Alkan, M. and Dogan, M., Adsorption of Copper (II) onto perlite. Journal of Colloid and Interface Science, 243, 280-291 (2001). https://doi. org/10.1006/jcis. 2001.7796
Alkan, M. and Dogan, M., Adsorption kinetics of victoria blue onto perlite. Fresenius Environ. Bull. 12 (2003) 418-425. Fresenius Environmental Bulletin, 12, 418-425 (2003).

Andrade, F. R. D. D., Polo, L. A., Janasi, V. D. A., \& Carvalho, F. M. D. S., Volcanic glass in Cretaceous dacitesandrhyolites oftheParanáMagmaticProvince, southern Brazil: Characterization and quantification by XRD-Rietveld. Journal of Volcanology and Geothermal Research, 355, 219-231 (2018). https:// doi.org/10.1016/j.jvolgeores.2017.08.008

Autié-Castro, G., Autié, M., Reguera, E., SantamaríaGonzález, J., Moreno-Tost, R., RodríguezCastellón, E. and Jiménez-López, A., Adsorption and separation of light alkane hydrocarbons by porous hexacyanocobaltates (III). Surface and Interface Analysis, 41, 730-734 (2009). https://doi. org/10.1002/sia.3080

Autié-Castro, G., Autié, M. A., Rodríguez-Castellón, E., Aguirre, C. and Reguera, E., Cu-BTC and Fe-BTC metal-organic frameworks: Role of the materials structural features on their performance for volatile hydrocarbons separation. Colloids and Surfaces A: Physicochemical and Engineering Aspects, 481, 351-357 (2015). https://doi. org/10.1016/j.colsurfa.2015.05.044

Batko, K. and Voelkel, A., Inverse gas chromatography as a tool for investigation of nanomaterials. Journal of Colloid and Interface Science, 315, 768-771 (2007). https://doi.org/10.1016/j.jcis.2007.07.028

Beerdsen, E., Dubbeldam, D., Smit, B., Vlugt, T.J.H. and Calero, S., Simulating the effect of nonframework cations on the adsorption of alkanes in MFI-type zeolites. The Journal of Physical Chemistry B, 107, 12088-12096 (2003). https:// doi.org/10.1021/jp035229q

Brian, B. F., Removal of Propylene from Fuel-Grade Propane. Separation \& Purification Reviews, 3, 157-182 (2004). https://doi.org/10.1081/SPM200042095

Brunauer, S., Emmett, P. H. and Teller, E., Adsorption of Gases in Multimolecular Layers. Journal of the American Chemical Society, 60, 309-319 (1938). https://doi.org/10.1021/ja01269a023

Cantergiani, E. and Benczédi, D., Use of inverse gas chromatography to characterize cotton fabrics and their interactions with fragrance molecules at controlled relative humidity. Journal of Chromatography A, 969, 103-110 (2002). https:// doi.org/10.1016/S0021-9673(02)00380-1

Correia, L. M., Campelo, N. S., Novaes, D. S., Cavalcante Jr., C. L., Cecilia, J. A., RodríguezCastellón, E. and Vieira, R. S., Characterization and application of dolomite as catalytic precursor for canola and sunflower oils for biodiesel production. Chemical Engineering Journal, 269, 35-43 (2015). https://doi.org/10.1016/j.cej.2015.01.097 
Dewar, M. J. S., A review of the 71-complex theory. Bulletin de la Societe Chimique de France, 18, C71-9 (1951).

Dogan, M. and Alkan, M., Removal of methyl violet from aqueous solution by perlite. Journal of Colloid and Interface Science, 267, 32-41 (2003). https:// doi.org/10.1016/S0021-9797(03)00579-4

Dogan, M., Alkan, M., Turkylmaz, A. and Ozdemir, Y., Kinetics and mechanism of removal of methylene blue by adsorption onto perlite. Journal of Hazardous Materials, 109, 141-148 (2004). https:// doi.org/10.1016/j.jhazmat.2004.03.003

Edelman,A. and Fradet,A., Inverse gas chromatography study of some triacetin-polymer systems. Polymer, 30, 317-323 (1989). https://doi.org/10.1016/00323861(89)90122-5

Eldridge, R. B., Olefin/paraffin separation technology: a review. Industrial \& Engineering Chemistry Research, 32, 2208-2212 (1993). https://doi. org/10.1021/ie00022a002

Farmer, V. C., Infrared Spectra of Minerals. Mineralogical Society, London, UK, p. 331 (1974). https://doi.org/10.1180/mono-4

Fernández-Hechevarría, H. M., Labadie Suarez, J. M., Santamaría-González, J., Infantes-Molina, A., Autié-Castro, G., Cavalcante Jr. C. L., RodríguezCastellón, E. and Autie-Pérez, M., Adsorption and separation of propane and propylene by Cuban Natural Volcanic Glass. Materials Chemistry and Physics, 168, 132-137 (2015). https://doi. org/10.1016/j.matchemphys.2015.11.012

Ferreira, A. F. P., Mittelmeijer-Hazeleger, M. C., Granato, M. A., Martins, V. F. D., Rodrigues, A. E. and Rothenberg, G., Sieving di-branched from mono-branched and linear alkanes using ZIF-8: experimental proof and theoretical explanation. Physical Chemistry Chemical Physics, 15, 87958804 (2013). https://doi.org/10.1039/c3cp44381g

Franco, F., Pozo, M., Cecilia, J. A., Benítez-Guerrero, M. and Lorente, M., Effectiveness of microwave assisted acid treatment on dioctahedral and trioctahedral smectites. The influence of octahedral composition. Applied Clay Science, 120, 70-80 (2016). https://doi.org/10.1016/j.clay.2015.11.021

Friedman, I. and Long, W., Volcanic glasses, their origins and alteration processes. Journal of NonCrystalline Solids, 67, 127-133 (1984). https://doi. org/10.1016/0022-3093(84)90144-3

Gomes, C. S. M., Farias, A. B., Guimarães, R. F., Oliveira, H. N. M. and Chiavone-Filho, O., Separation of heavy species (C5+) from natural gas using absorption. Brazilian Journal of Petroleum and Gas, 8, 73-80 (2014). https://doi.org/10.5419/ bjpg2014-0006

Grimsey, I. M., Feeley, J. C. and York, P., Analysis of the surface energy of pharmaceutical powders by inverse gas chromatography. Journal of Pharmaceutical Sciences, 91, 571-583 (2002). https://doi.org/10.1002/jps.10060

He, W., Lu, G., Cui, J., Wu, L. and Liao, L., Regeneration of spent activated carbon by yeast and chemical method. Chinese Journal of Chemical Engineering, 20, 659-664 (2012). https://doi. org/10.1016/S1004-9541(11)60232-2

Heng, J. Y. Y., Pears, D. F., Thielmann, F., Lampke, T. and Bismark, A., Methods to determine surface energies of natural fibres: a review. Composite Interfaces, 14, 581-604 (2007). https://doi. org/10.1163/156855407782106492

Huang, H., He, Z., Yuan, H., Chen, Y. and Kobayashi, N., Evaluation of n-butane gas adsorption performance of composite adsorbents used for carbon canister. Procedia Engineering, 18, 78-85 (2011). https:// doi.org/10.1016/j.proeng.2011.11.013

Keltsev, K. V. The essential principles of adsorption engineering. Khimia, Moscow (1984).

Laredo, G.C., Trejo-Zarraga, F.; Jiménez-Cruz, F., García-Gutiérrez, J.L., Separation of Linear and Branched Paraffins by Adsorption Processes for Gasoline Octane Number Improvement. Recent Patents on Chemical Engineering, 5, 153-173(2012). https://doi.org/10.2174/2211334711205030001

Lazarević, S., Radovanović, Ž., Veljović, Dj., Onjia,A., Janaćković, Dj., Petrović,R. Characterization of sepiolite by inverse gas chromatography at infinite and finite surface coverage. Applied Clay Science, 43, 41-48 (2009). https://doi.org/10.1016/j. clay.2008.07.013

Madejová, J., FTIR techniques in clay mineral studies. Vibrational Spectroscopy, 31, 1-10 (2003). https:// doi.org/10.1016/S0924-2031(02)00065-6

Menzel, R., Lee, A., Bismarck, A. and Shaffer, M. S. P., Inverse gas chromatography of as-received and modified carbon nanotubes. Langmuir, 25, 83408348 (2009). https://doi.org/10.1021/1a900607s

Merkel, T. C., Blanc, R., Ciobanu, I., Firat, B., Suwarlim, A. and Zeid, J., Silver salt facilitated transport membranes for olefin/paraffin separations: Carrier instability and a novel regeneration method. Journal of Membrane Science, 447, 177-189 (2013). https://doi.org/10.1016/j.memsci.2013.07.010

Mohammadi-Jan, S. and Waters, K. E., Inverse gas chromatography applications: A review. Advances in Colloid and Interface Science, 212, 21-44 (2014). https://doi.org/10.1016/j.cis.2014.07.002

Murakami, Y., Enoki, R., Ogoma, Y. and Kondo, Y., Studies on interaction between silica gel and polymer blend by inverse gas chromatography. Polymer Journal, 30, 520-525 (1998). https://doi. org/10.1295/polymj.30.520

Planinsek, O. and Buckton, G., Inverse gas chromatography: Considerations about appropriate 
use for amorphous and crystalline powders. Journal of Pharmaceutical Sciences, 92, 1286-1294 (2003). https://doi.org/10.1002/jps.10394

Rivera, A., Farías, T., de Ménorval, L. C., Autié-Castro, G., Yee-Madeira, H., Contreras, J. L. and Autié-Castro, M., Acid natural clinoptilolite: Structural properties against adsorption/separation of n-paraffins. Journal of Colloid Interface Science, 360, 220-226 (2011). https://doi.org/10.1016/j.jcis.2011.04.035

Ruggieri, F., Marín, V., Gimeno, D., FernándezTuriel, J. L., García-Vallés, M. and Gutiérrez, L., Application of zeolitic volcanic rocks for arsenic removal from water, Engineering Geology, 101，245-250 (2008). https://doi.org/10.1016/j. enggeo.2008.06.006

Steinhauser, G. and Bichler, M., Adsorption of ions onto high silica volcanic glass. Radioactivity and Radionuclide Applications, 66, 1-8 (2008). https:// doi.org/10.1016/j.apradiso.2007.07.010

Tekin, M., Dincer, A., Demirbas, O. and Alkan, M., Adsorption of cationic polyacrylamide (C-PAM) on expanded perlite. Applied Clay Science, 50, 125-129 (2010). https://doi.org/10.1016/j. clay.2010.07.014

Thommes, M., Kaneko, K., Neimark, A. V., Oliver, J. P., Rodríguez-Reinoso, F., Rouquerol, J. and Sing, K. S. W., Physisorption of gases, with special reference to the evaluation of surface area and pore size distribution (IUPAC Technical Report). Pure and Applied Chemistry, 87, 1051-1069 (2015). https://doi.org/10.1515/pac-2014-1117

Tomita, K., Yamane, H. and Kawano, M., Synthesis of smectite from volcanic glass at low temperature.
Clays and Clay Minerals, 41, 655-661 (1993). https://doi.org/10.1346/CCMN.1993.0410603

Torres-Ortega, C. E., Segovia-Hernández, J. G., Gomez-Castro, F. I., Hernández, S., Rong, B. G. and Errico, M., Design and optimization of a process based on extractive distillation for the sweetening natural gas. Chemical Engineering Transactions, 32, 1357-1362 (2013).

Vilarrasa-García, E., Cecilia, J. A., Azevedo, D. C. S., Cavalcante Jr., C. L. and Rodríguez-Castellón, E., Evaluation of porous clay heterostructures modified with amine species as adsorbent for the $\mathrm{CO} 2$ capture. Microporous and Mesoporous Materials. 249, 25-33 (2017). https://doi.org/10.1016/j. micromeso.2017.04.049

Voelkel, A., Strzemiecka, B., Adamska, K. and Milczewaska, K., Inverse gas chromatography as a source of physiochemical data. Journal of Chromatography A, 1216 1551-1566 (2009). https://doi.org/10.1016/j.chroma.2008.10.096

Yahia, S. B. and Ouederni, A., Hydrocarbons gas storage on activated carbons. International Journal of Chemical Engineering and Applications, 3(3), 220-227 (2012). https://doi.org/10.7763/ IJCEA.2012.V3.190

Yoshida, A. and Inoue, K., Formation of faujasite-type zeolite from ground Shirasu volcanic glass. Zeolites, 6, 467-473 (1986). https://doi.org/10.1016/01442449(86)90031-X

Yoshida, A. and Inoue, K., Whiteness in zeolite A prepared from Shirasu volcanic glass. Zeolites, 8, 94-100 (1988). https://doi.org/10.1016/S01442449(88)80072-1 
